\title{
Nucleic Acid Contents of Japanese Foods
}

\author{
Makoto TAJIMA ${ }^{*, * *}$, Noriko Matsumoto-Koy AmA ${ }^{*}$ and \\ Yasuko Nishio-KozU* \\ * National Food Research Institute, Ministry of Agriculture, Forestry and \\ Fisheries, 2-1-2, Kannondai, Tsukuba, Ibaraki 305 \\ ** Present address; Chugoku National Agricultural Experiment Station, \\ Fukuyama, Hiroshima 721
}

\begin{abstract}
Nucleic acid contents of 29 kinds of Japanese foods, including 7 kinds of meats and poultries, 3 kinds of eggs, 11 kinds of seafoods, 2 kinds of cereals, 2 kinds of legumes, 2 kinds of fungus, 1 kind of fruit and 1 kind of yeast, were determined by ScHMIDT-THANNHAUSER-SCHNEIDER method or ion-exchange chromatography. The nucleic acid contents of almost all samples were in the range of 200 to $400 \mathrm{mg}$ per $100 \mathrm{~g}$ of fresh weight. The samples with high nucleic acid content were pork liver, salmon roe, purple laver and baker's yeast. Although proportion ratio of nucleic acid nitrogen to total nitrogen of almost all the samples was $2 \%$, that of the samples containing high nucleic acid was more than $10 \%$.
\end{abstract}

Purine and pyrimidine bases of nucleic acid in foods arouse interest in human nutrition by several reasons. One is that purine base causes the gout on humans. ${ }^{1)}$ The intake from food should be limited from this point. On the contrary, in recent years, high nucleic acid commodities are sold as a healthy food, even though its academic background is not established.

In this paper, we describe the nucleic acid content of Japanese foods. The nucleic acid content of Japanese foods was reported by NOZAKI et al. in 1971. ${ }^{2)}$ However, the reported value was not recognized as accurate because of their analytical method. In 1977, 1981 and 1982, MAtsumoto ${ }^{3)}$ and Shinoda et al. ${ }^{4) 5 \text { ) }}$ reported the nucleic acid contents of meats, fishes, cereals, beans, eggs, milk and vegetables. However, they estimated the purine bases only.

In this study, we estimated not only purine bases but also pyrimidine bases, because the nucleic acid contents affect the nitrogen-factor in calculation for protein content of foods from Kjeldahl-nitrogen. The sum of the content of purine and pyrimidine bases corresponds to some part of non-protein nitrogen.

\section{Experimental}

\section{Materials}

Twenty-nine kinds of food samples listed below were analyzed.

Meats and poultries; beef (cattle), pork (swine), chicken (hen), pressed ham, pork liver, liver paste, organs of chicken

Eggs; whole egg, yolk, egg white

Seafoods; tuna, flatfish, maiwashi (anchovy), short-necked clam, kegani (crab), tiger prawn, salmon roe, salmon milt, jellyfish, oyster, dried purple laver

Legumes ; soybean, adzuki bean

Cereals ; rice, wheat

Fruit ; banana

Fungus ; Shiitake (Lentinus edodes), common mushroom (Agaricus bisporus)

Yeast ; dried baker's yeast (Saccharomyces cerevisiae)

All samples were collected from the market in Tokyo.

\section{Preparation of samples}

On all samples only edible parts were analyzed according to the description of the Standard Tables of Japanese Foods ${ }^{6)}$. Samples were washed by tap-water, wiped by cloth and 
cut into small pieces.

\section{Analytical methods}

Moisture content was determined by drying under reduced pressure $(20-30 \mathrm{mmHg})$ at $90^{-}$ $100^{\circ} \mathrm{C}^{7)}$. Nitrogen content was determined by semi-micro Kjeldahl method. ${ }^{8)}$

Nucleic acid contents of the samples from animal origin were determined by SCHMIDTTHANNHAUSER-SCHNEIDER method (STS method) with slight modification. ${ }^{9)}$ Perchloric acid was used as extraction reagent in place of trichloroacetic acid. Although the extract of $5 \%$ perchloric acid solution contained free bases,nucleosides, nucleotides and other nonnucleic acid acid-soluble compounds, we estimated this fraction as acid-soluble nucleic acid fraction by measuring O.D. at $260 \mathrm{~nm}$. In order to confirm this assumption was proper or not, the comparative analysis between STS method and ion-exchange chromatography was carried out. The results were described in the Results section.

Nucleic acid contents of the samples from plant origin were determined by ion-exchange chromatography after the fractionation by STS method. The column used was Dowex-1 (X-8) 200-400 mesh) and eluted by diluted hydrogen chloride solution containing sodium chloride ${ }^{9)}$.

Amino acid contents of some samples were determined by amino acid analyzer (Hitachi KLA-5) after hydrolysis by $6 \mathrm{~N}$ hydrogen chloride at $105^{\circ} \mathrm{C}$ for $22 \mathrm{~h}$.

\section{Results}

Comparison of the data obtained by two methods, STS method and ion-exchange chromatography

To determine nucleic acid contents in foods, STS method is very convenient. However, in this method nucleic acid can be examined by UV absorption, so, it may cause over-estimation of the contents if the sample contains non-nucleic acid acid-soluble UV-absorbed compounds. To confirm this possibility, we estimated some samples by both methods, STS method and ion-exchange chromatography.

As the results listed in Table 1, the samples from animal origin, such as beef and pork, showed almost the same value (96 and $92 \%$ each) between two methods. On the contrary, the samples from plant origin, such as rice, soybean and banana, showed relatively different value $(8.6,61$ and $7.0 \%$, respectively) between two methods. From these results, we concluded that STS method was effective to analyze the samples from animal origin and the chromatographic method to that from plant origin.

Nucleic acid contents of Japanese foods

Table 2 shows the nucleic acid contents of 29 kinds of Japanese foods. The values listed in the Table express the weight of bases moiety of nucleic acids. Acid soluble fraction contains free bases, nucleosides and nucleotides. RNA or DNA fraction corresponds to bases of RNA or DNA, respectively. Nucleic acid nitrogen was calculated from the total nucleic acid with the assumption that average nitrogen content of bases was $15.3 \%$.

Proportion ratio of nucleic acid nitrogen

Table 1 Acid soluble nucleic acid content of some samples determined by STS method and ion-exchange chromatography

\begin{tabular}{lcc}
\hline Name of samble & STS method & $\begin{array}{l}\text { Ion-exchange } \\
\text { chromatography }\end{array}$ \\
\hline Beef (Cattle) & $265^{11}$ & $254^{21}$ \\
Pork (Swine) & 125 & 115 \\
Rice & 349 & 30 \\
Soybean & 190 & 116 \\
Banana & 243 & 17 \\
\hline
\end{tabular}

1) The values were calculated from the UV absorption at $260 \mathrm{~nm}$.

2) The values were estimated from the area of the chromatogram. 
Table 2 Nucleic acid content of selected foods*

\begin{tabular}{|c|c|c|c|c|}
\hline \multirow{2}{*}{ Name of sample } & \multicolumn{3}{|c|}{ Fractions } & \multirow{2}{*}{ Total } \\
\hline & Acid soluble & RNA & DNA & \\
\hline \multicolumn{5}{|l|}{ Meats and poultries } \\
\hline Beef (cattle) & 265 & 130 & 78 & 473 \\
\hline Pork (swime) & 125 & 77 & 40 & 242 \\
\hline Chicken (hen) & 332 & 147 & 47 & 526 \\
\hline Pressed ham & 153 & 43 & 50 & 246 \\
\hline Pork liver & 262 & 452 & 164 & 878 \\
\hline Liver paste & 233 & 215 & 111 & 559 \\
\hline Organs of chicken & 156 & 192 & 112 & 460 \\
\hline \multicolumn{5}{|l|}{ Eggs } \\
\hline Whole egg & 37 & 40 & 33 & 110 \\
\hline Yolk & 14 & 102 & 19 & 135 \\
\hline Egg white & 28 & 21 & 13 & 62 \\
\hline \multicolumn{5}{|l|}{ Fishes } \\
\hline Tuna & 343 & 72 & 30 & 445 \\
\hline Flatfish & 257 & 110 & 59 & 426 \\
\hline Maiwashi (sardine) & 267 & 126 & 77 & 469 \\
\hline Short necked clam & 242 & 307 & 494 & 1043 \\
\hline Kegani (crab) & 193 & 59 & 45 & 297 \\
\hline Tiger prawn & 309 & 58 & 27 & 394 \\
\hline Jelly fish & 32 & 250 & 32 & 314 \\
\hline Oyster & 387 & 382 & 133 & 902 \\
\hline Purple laver & 621 & 2551 & 335 & 3507 \\
\hline Salmon roe & 104 & 45 & 19 & 168 \\
\hline Salmon milt & 138 & 219 & 897 & 1254 \\
\hline \multicolumn{5}{|l|}{ Cereals } \\
\hline Rice & 30 & 145 & 60 & 235 \\
\hline Wheat & 25 & 96 & 72 & 193 \\
\hline \multicolumn{5}{|l|}{ Legumes } \\
\hline Soybean & 116 & 620 & 216 & 952 \\
\hline Adzuki bean & 35 & 311 & 32 & 378 \\
\hline \multicolumn{5}{|l|}{ Fruit } \\
\hline Banana & 17 & 31 & 4 & 53 \\
\hline \multicolumn{5}{|l|}{ Fungus } \\
\hline Shiitake (Lentinus edodes) & 27 & 43 & 13 & 83 \\
\hline Common mushroom (Agaricus bisporus) & 45 & 90 & 4 & 134 \\
\hline \multicolumn{5}{|l|}{ Yeast } \\
\hline Baker's yeast (Saccharomyces cerevisiae) & 1561 & 5054 & 267 & 6882 \\
\hline
\end{tabular}

* The value expressed the $\mathrm{mg}$ of bases per $100 \mathrm{~g}$ of fresh weight.

to total nitrogen

Table 3 shows the contents of nucleic acid nitrogen and total nitrogen estimated by
Kjeldahl method and the proportion ratio of nucleic acid nitrogen to total nitrogen. 
Table 3 Nucleic acid and total nitrogen contents of selected foods ( $\%$ )

\begin{tabular}{|c|c|c|c|}
\hline Name of sample & $\begin{array}{l}\text { Nucleic acid } \mathrm{N} \\
\text { (A) }\end{array}$ & $\begin{array}{l}\text { Total N } \\
\text { (B) }\end{array}$ & (A) $/(B) \times 100$ \\
\hline \multicolumn{4}{|l|}{ Meats and poultries } \\
\hline Beef (cattle) & 0.0724 & 2.31 & 2.19 \\
\hline Pork (swime) & 0.0371 & 2.57 & 1.44 \\
\hline Chicken (hen) & 0.0805 & 3.88 & 2.08 \\
\hline Pressed ham & 0.0375 & 2.03 & 1.86 \\
\hline Pork liver & 0.1343 & 2.95 & 4.55 \\
\hline Liver paste & 0.0855 & 1.44 & 5.94 \\
\hline Organs of chicken & 0.0704 & 2.58 & 2.73 \\
\hline \multicolumn{4}{|l|}{ Eggs } \\
\hline Whole egg & 0.0168 & 1.92 & 0.88 \\
\hline Yolk & 0.0206 & 2.29 & 0.90 \\
\hline Egg white & 0.0094 & 1.53 & 0.62 \\
\hline \multicolumn{4}{|l|}{ Fishes } \\
\hline Tuna & 0.0680 & 3.66 & 1.86 \\
\hline Flatfish & 0.0651 & 3.43 & 1.90 \\
\hline Maiwashi (sardine) & 0.0769 & 2.76 & 2.61 \\
\hline Short necked clam & 0.160 & 2.13 & 7.51 \\
\hline Kegani (crab) & 0.0454 & 2.13 & 2.13 \\
\hline Tiger prawn & 0.0603 & 2.88 & 2.05 \\
\hline Jelly fish & 0.0480 & 0.96 & 5.00 \\
\hline Oyster & 0.138 & 1.52 & 9.05 \\
\hline Purple laver & 0.537 & 6.29 & 8.53 \\
\hline Salmon roe & 0.0257 & 2.38 & 1.08 \\
\hline Salmon milt & 0.192 & 1.23 & 15.6 \\
\hline \multicolumn{4}{|l|}{ Cereals } \\
\hline Rice & 0.360 & 0.953 & 3.78 \\
\hline Wheat & 0.0295 & 2.07 & 1.43 \\
\hline \multicolumn{4}{|l|}{ Legumes } \\
\hline Soybean & 0.146 & 6.45 & 2.26 \\
\hline Adzuki bean & 0.0578 & 3.12 & 1.85 \\
\hline \multicolumn{4}{|l|}{ Fruit } \\
\hline Banana & 0.008 & 0.165 & 4.87 \\
\hline \multicolumn{4}{|l|}{ Fungus } \\
\hline Shiitake (Lentinus edodes) & 0.0127 & 0.521 & 2.44 \\
\hline $\begin{array}{l}\text { Common mushroom (Agaricus bisporus) } \\
\text { Yeast }\end{array}$ & 0.0205 & 0.685 & 2.99 \\
\hline Baker's yeast (Saccharomyces cerevisiae) & 1.053 & 7.51 & 14.0 \\
\hline
\end{tabular}

\section{Discussion}

The nucleic acid contents of Japanese foods were shown in Table 2. Almost all of the foods from animal origin contained several- hundred $\mathrm{mg}$ of nucleic acid per $100 \mathrm{~g}$ of fresh weight. Furthermore, it was interested that cereals and legumes also contained such amount of nucleic acids.

Comparing our data with those of MATsU- 
Table 4 Total nucleic acid and amino acids contents of the foods which have high nucleic acid contents"

\begin{tabular}{|c|c|c|c|c|}
\hline Name of sample & Nucleic acids(A) & Amino $\operatorname{acids}^{2)}(\mathrm{B})$ & $(A)+(B)$ & Amide- $\mathrm{N}^{31}$ \\
\hline Short-necked clam & 7.5 & 72.9 & 80.4 & 5.5 \\
\hline Purple laver & 8.5 & 72.7 & 81.7 & 4.2 \\
\hline Baker's yeast & 14.0 & 80.1 & 94.1 & 5.6 \\
\hline
\end{tabular}

1) The values expressed as nitrogen $\mathscr{W}$ of each fraction of total nitrogen content.

2) Cystine and tryptophan were not included.

3) Reported by Yamaguchi, M.; "Report of the Research on Analysis of Minor-component of Foods", p. 269 (Science and Technology Agency, Japan) (1979)

MOTO and SHINODA ${ }^{4) 5}$, it was found that our data were slightly higher than those of them. This result was reasonable because our data include purine and pyrimidine bases on the contrary to that their data include purine base only.

Proportion ratio of nucleic acid nitrogen to total nitrogen was listed in Table 3 . It can be seen that the ratio of almost all the samples not only from animal origin but also plant origin is around $2 \%$. This fact indicates that "nitrogen-protein factor" used in determination of protein content by Kjeldahl method must consider nucleic acid nitrogen. If we estimate protein content by calculation of Kjeldahl nitrogen multiplied by nitrogenprotein factor, usually 6.25 , it would be overestimated. We must subtract nucleic acid nitrogen from total nitrogen.

In order to confirm the suggestion, total amino acid content of some samples were determined. Table 4 showed the total nucleic acid and total amino acid contents of the foods which have high nucleic acid content. The sum of the nucleic acid nitrogen and the amino acid nitrogen was $80.4,81.7$ and $94.1 \%$ of total nitrogen, respectively. This figures indicate the existence of the other nitrogenous compounds in these foods, one of which is amidenitrogen. The contents of amide-nitrogen in these foods reported by YAMAGUCHI were shown in Table 4. The fact that sum of the content of these compounds does not exceed 100 $\%$ indicates the following conclusion. Protein contents in foods should be estimated by total amino acid contents.

\section{References}

1) Clifford, A.J. and Story, D.L. : J. Nutr., 106, 435 (1976).

2) Nozaki, Y. and Matsumura, Y.: Nihonjyoshidaigaku-kiyo, 18, 13 (1971).

3) Matsumoto, M., Aoyagi, Y. and SugaHARA, T.: Eiyo to Shokuryo, 30, 155 (1977).

4) Shinoda, T., Aoyagi, Y. and Sugahara, T. : Eiyo to Syokuryo, 34, 153 (1981).

5) Shinoda, T., Aoyagi, Y. and Sugahara, T. : Eiyo to Shokuryo, 35, 103 (1982).

6) Science and Technology Agency ed.: "Standard Tables of Food Composition in Japan" (1982).

7) Jap. Soc. Food Sci. and Technol. ed.: "Shokuhinbunseki-ho (Food Analysis)", p. 8 (Korin, Tokyo) (1984).

8) Jap. Soc. Food Sci. and Technol. ed.: "Shokuhinbunseki-ho (Food Analysis)", p. 563 (Korin, Tokyo) (1984).

9) Jap. Soc. Food Sci. and Technol. ed.: "Shokuhinbunseki-ho (Food Analysis)", p. 567 (Korin, Tokyo) (1984).

(Received Dec. 26, 1988)

\section{日本食品の核酸含型}

$$
\begin{aligned}
& \text { 田島 椇* ・小山（松本）典子* } \\
& \text { 木津 (西尾) 泰子* } \\
& \text { *食品総合研究所 } \\
& \text { （干305 茨城県つく岒市観音台 2-1-2） }
\end{aligned}
$$

日本食品 29 点（鳥獣肉類 7 点，卵類 3 点，魚介類 11 点, 海藻 1 点, 款類 2 点, 豆類 2 点, きのこ類 2 点, 果 実 1 点, 酵母 1 点) の全核酸含量を，SCHMIDT-THAN- 
NHAUSER-SCHNEIDER 法ならびにイオン交換クロマト グラフィーにより測定した。分析した試料の全核酸含量 は，植物性食品を含め，大部分のものは 200〜 400 mg/ $100 \mathrm{~g}$ の範囲であった。核酸含量の高い6のは，豚レバ
一，鮭白子，乾燥海苔，パン酵母などであっだ。全坴 素に占める核酸態窒素の割合は，大部分の鉽料では $2 \%$ 前後であったが，これらの高いものでは10\%を越える ものがあった。 